\title{
PETROLEUM GEOLOGY OF THE DUTCH CENTRAL NORTH SEA GRABEN
}

\section{Extended Abstract}

\author{
Th. E. Wong \\ Geological Survey of The Netherlands, P.O. Box 157, 2000 AD Haarlem, The Netherlands
}

This contribution presents an extended abstract intended for the proceedings of the symposium: The Jurrassic in the Southern Central Graben (Hørsholm, Denmark, June $15-16,1989$ ). It generally covers the stratigraphic and petroleum geological aspects of the paper entitled: "Late Jurassic" petroleum geology of the Dutch Central North Sea Graben presented by Th. E. Wong, Th. H.M. Van Doorn and B.M. Schroot at the 78th annual meeting of the Geologische Vereinigung (Jülich, febr. 24-26, 1988). The full text has been published in Geologische Rundschau, 78, 1989, pp. 319-336. The structural and seismic aspects are delt with in detail by B.M. Schroot in the present volume

\section{Brief Structural and Stratigraphic Setting.}

The area has been subdivided into a number of structural elements: platform, intermediate platform, outer graben and inner graben (Fig. 1). Characteristic features defining these elements are: typical depth of the prerift basement, boundary fault systems and the post-Permian stratigraphic sequence. In the northern part of the area the elements can be easily recognized because intense rifting caused substantial throw at the faults. Toward the south the situation is less distinct, becoming even rather arbitrary at the southeastern end of the Central North Sea Graben, which was only subjected to limited rifting.

It is evident that the lithological record in the Central North Sea Graben reflects the complex geological history of the area. Superimposed on the normal rifting configuration there are features such as: considerable strike-slip components of the faulting, intensive halokinesis and inversion. Although rifting was apparent since the Triassic, the major rifting phase took place during the Late Jurassic. In this context, the sediments can be grouped as follows (see fig. 2 for more details):

a) Pre-rift sediments (Carboniferous - Middle Jurassic)

b) Syn-rift sediments (Late Jurassic)

c) Post-rift sediments (Cretaceous-Quaternary)

\section{Prospectivity}

\section{Source Rocks}

\section{Carboniferous}

The coal-bearing strata of the Westphalian A-C are the main gas source rocks and are present in the (intermediate) platform areas (fig. 1). In the central part of the graben, wells have never reached Carboniferous rocks so that their presence can only be inferred from the regional geology. The main kerogen type of the coal-bearing strata is vitrinite (type III kerogen). Basin modelling showed that the top of the Carboniferous entered the gas generating window at different times across the Central North Sea Graben. On the intermediate platform in the SE part of the area, the top of the 
Westphalian became mature in the Tertiary. In the outer graben, this already took place in the Late Jurassic to Early Cretaceous.

\section{Late Triassic - Early Jurassic}

The Late Triassic Sleen Shale and the Early Jurassic Aalburg Shale contain not only ma- rine algal sapropel, but locally also large amounts of land derived organic material. Although both shales can be considered as source rocks mainly for gas, their contribution to known gasfields in the region seems to be rather limited. The overlying Posidonia Shale, occurring in the inner and outer graben areas, is the principal oil source rock

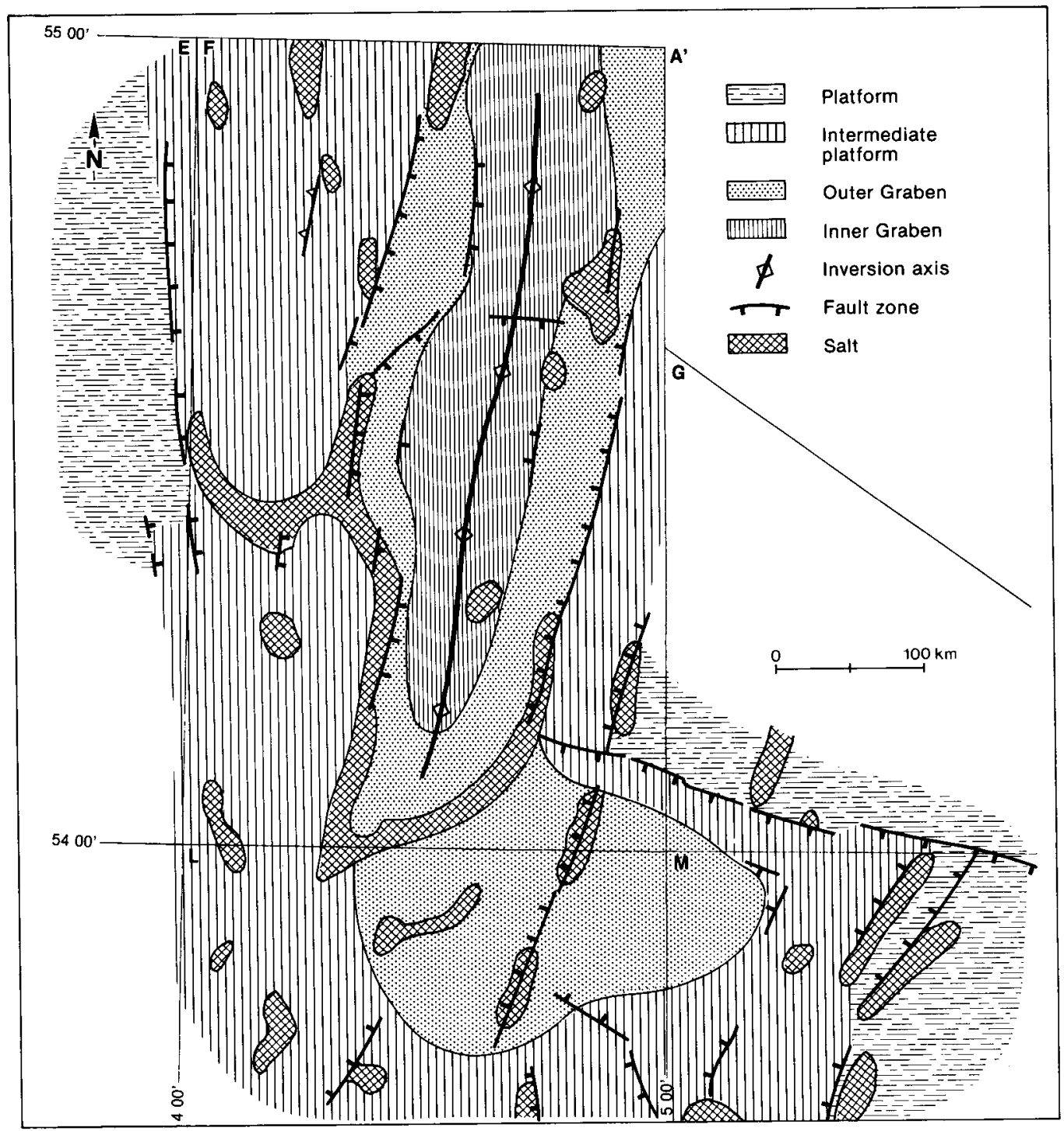

Fig. 1 General outline of the Dutch Central North Sea Graben, showing major structural elements, inversion axes, salt domes and piercements. 
in the Netherlands. Both marine algal sapropel and land derived organic material are present (type II kerogen), implying that both oil and gas can be generated, depending on the depth of the burial. This could be the case in the F03 oil/condensate field of the NAM (located in the inner graben) where modelling suggests that the Posidonia and other Altena shales already arrived in the wet gasgeneration phase in the Jurassic.

\section{Late Jurassic - Early Cretaceous}

The Middle Graben Shale, Puzzle Hole and Delfland Formations are considered to be gas-prone, but overall they must be ranked among the minor source rocks. The bituminous Clay Deep Formation in the northern $F$ and $B$ quadrants is characterized by marine algal sapropel of the type I kerogen. In this area this formation may have been buried deeply enough to have entered the oil generating window. Contemporaneous "hot shales" in the Norwegian and Danish sectors of the Central Graben constitute the major oil source rock in those areas.

\section{Reservoir Rocks}

\section{Carboniferous}

Late Carboniferous sandstones are believed to be present in the intermediate areas but the reservoir characteristics may have been destroyed by diagenesis. Moreover, the sandstones are likely to be thin and laterally discontinuous. For these reasons, Upper Carboniferous reservoir potential is considered to be high risk.

\section{Permian}

Only a rather thin section of the Lower Slochteren Sandstone (Rotliegend) is expected in the southern part of the Central North Sea Graben. Reservoir quality is expected to be fair to poor.

\section{Triassic}

The sandstone units of the Main Buntsandstein Formation constitute one of the primary reservoir objectives for gas in the outer graben and the (intermediate) platform areas. In the western area of the southeastern part of the Central North Sea Graben various Buntsandstein prospects can be identified. Nearby gasfields have demonstrated that the productivity of these sands is good, but deep burial and salt plugging (near salt structures) could have caused significant reservoir degradation.

\section{Jurassic}

The Upper Jurassic comprises the following clastic units which have good reservoir characteristics: Lower Graben Sand, Upper Graben Sand, Puzzle Hole, Delfland and Scruff Greensand Formations. The Lower Graben Sand Formation is the main reservoir in the $\mathrm{F} 02$ and $\mathrm{F} 03$ gas/condensate field. In this area the Upper Graben Sand constitutes a secondary objective. The occurrence of the Lower Graben Sand is limited to the inner and outer graben, not extending south of the $F$ quadrant. Various sub-economic oil occurrences have been recorded from a number of locations in the Delfland and Puzzle Hole Formations. For the latter formation this may be due to the limited lateral extent of the individual sand units. To a lesser degree this may also be the case with the Delfland Formation, but the patchy development of the Posidonia source rock below this formation could also explain the poor oil shows. The prospectivity of the Scruff Greensand Formation has been disappointing so far. This may be explained by the rapid changes in permeabilities within this formation. It is assumed that both Delfland and Scruff Greensand may be gasbearing in the southeastern extension of the Central North Sea Graben. Significant sections of these formations have been identified on seismic sometimes in a favourable setting for the trapping of Carboniferous 


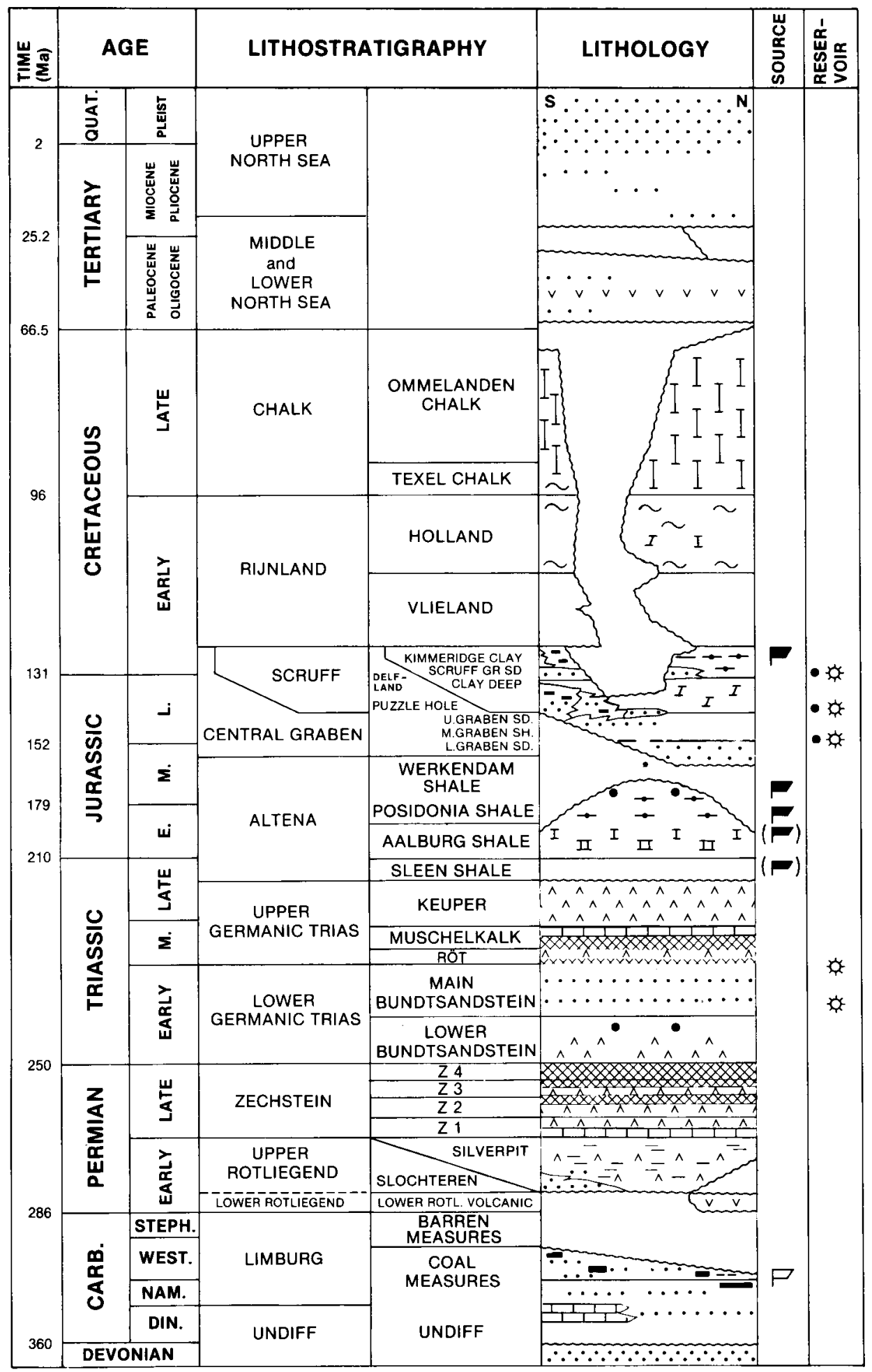

Fig. 2 Stratigraphic diagram of the Dutch Central North Sea Graben, showing gas (open symbol) and oil (solid symbol) source rocks, and reservoir rocks. 
gas. Consequently, this forms a new play concept in the Dutch offshore exploration.

\section{Cretaceous}

Although only minor oil shows have been reported in the Chalk from this area, there still remains a theoretical possibility of hydrocarbon accumulations within this unit. Especially, when specific conditions like redeposition or fracturing have enhanced the porosities and permeabilities.

\section{Tertiary and Quaternary}

Since this interval comprises major sand developments which have hardly been deformed, it may contain stratigraphic traps. These traps may have been charged with gas leaking up along major faults.

\section{Conclusion}

In the inner and outer graben areas of the Dutch Central North Sea Graben, various oil accumulations in Upper Jurassic sands have been recorded. The oil originated from the Posidonia Shale, an organic-rich Lower Jurassic unit. Outside this area this unit will not contribute much to oil generation due to its patchy development. The remaining prospective area in the Central North Sea Graben is its relatively unexplored southeastern extension which, as part of a military shooting zone, has formerly been closed for exploration activities (it has been included, under special restrictions, in the Dutch 7th bidding round for off-shore exploration licences).

Structurally this area is part of the outer graben and intermediate platform which have good prospectivity for gas (sourced from the Carboniferous Coal Measures) in Triassic (Main Buntsandstein) and Late Jurassic (Delfland and Scruff Greensand) reservoir rocks. 